\title{
Pengaruh Kemisikinan Terhadap Akses Pendidikan Bagi Anak Nelayan di Aceh Selatan
}

\author{
Wini Delvia Riski, Vellayati Hajad \\ Fakultas Ilmu Sosial dan Ilmu Politik, Universitas Teuku Umar, Aceh, Indonesia
}

\begin{tabular}{|c|}
\hline ARTICLE INFORMATION \\
\hline $\begin{array}{l}\text { Received: February 18, } 2021 \\
\text { Revised: March 28, } 2021 \\
\text { Accepted: April 26, } 2021 \\
\text { Available online: April 29, } 2021\end{array}$ \\
\hline KEYWORDS \\
\hline Poverty, Fishermen, Income, Education \\
\hline CORRESPONDENCE \\
\hline $\begin{array}{l}\text { Phone : } 081377040471 \\
\text { E-mail :vellayati.hajad@utu.ac.id }\end{array}$ \\
\hline
\end{tabular}

\section{A B S T R A C T}

\begin{abstract}
The aim of this study is to analyze the impact of poverty on access to education for fishermen's children in the South Aceh District. Poverty is a condition that causes a person to be unable to enjoy health, higher education and to consume adequate food from a health perspective. As a result, they have low productivity, decent work and low incomes. The method used is quantitatively explained by the creation of 18 fishermen in Ujung Tanah Village, Samadua District, South Aceh Regency.Data was obtained through questionnaires and interviews and analyzed through a Spearman correlation test using the IBM SPSS Statistics Version 20 software to test the influence between variables and explain the relationship between the two. Research data shows that at $S D$ level $p>0.05$, SMP $p>0.05$, SMA $p>0.005$, S1 p>0.005. In the meantime, the value of the correlation test is -0.252 (SD), -0.258 (SMP), -0.140 (SMA), -0.129 (SI). The conclusion is, therefore, that the hypothesis $(\mathrm{Ho})$ is accepted, that is, that there is an influence between poverty $(X)$ and education $(\mathrm{Y})$ on the children of fishermen with a negative or opposite correlation. Namely, the higher the poverty, the lower the education of the children of fishermen.
\end{abstract}

\section{PENDAHULUAN}

Kemiskinan adalah sebuah situasi dan keadaan serba kekurangan yang dialami oleh seseorang atau sekelompok orang yang menyebabkan orang tersebut tidak mampu menikmati kesehatan yang layak, pendidikan yang tinggi, dan konsumsi makanan yang layak dari sisi kesehatan. Orang yang mengalami kemiskinan memiliki produktivitas yang rendah karena tidak memiliki kualitas untuk mendapat pekerjaan yang layak (Agusta 2014; Alfian 1980; Kuncoro 2002). Akibatnya, pertumbuhan ekonomi dan pendapatan juga menjadi rendah sehingga tidak mampu memenuhi sandang, pangan, dan papan yang layak. Kondisi orang miskin yang terjebak dalam sebuah lingkaran kemiskinan yang tidak berujung pangkal sering disebut lingkaran setan (Seran 2017).

Sedangkan menurut United Nations Development Programme (UNDP), kemiskinan masih terbatas pada definisi ketidakberdayaan untuk memperluas pilihan-pilihan hidup. Oleh karena itu, partisipasi masyarakat miskin dalam pengambilan kebijakan publik menjadi salah satu indikator kemiskinan yaitu dengaan mengukur dan membandingkan tingkat konsumsi penduduk dengan garis kemiskinan atau jumlah rupiah untuk konsumsi orang per bulan. Melalui ukuran tersebut maka akan terlihat dan dibedakan apakah seseorang miskin atau tidak miskin. Di Aceh, kemiskinan sudah berusaha dikurangi dan diatasi dengan pemberian dana Otonomi Khusus yang khusus dirancang untuk membangun kembali Aceh Pascakonflik dan tsunami (Ikhsan 2015). Meskipun demikian, angka kemiskinan di Aceh tidak kunjung berkurang, apalagi jika dibandingkan dengan besarnya anggaran otonomi khusus yang diterima oleh Aceh (Okezone 2018).

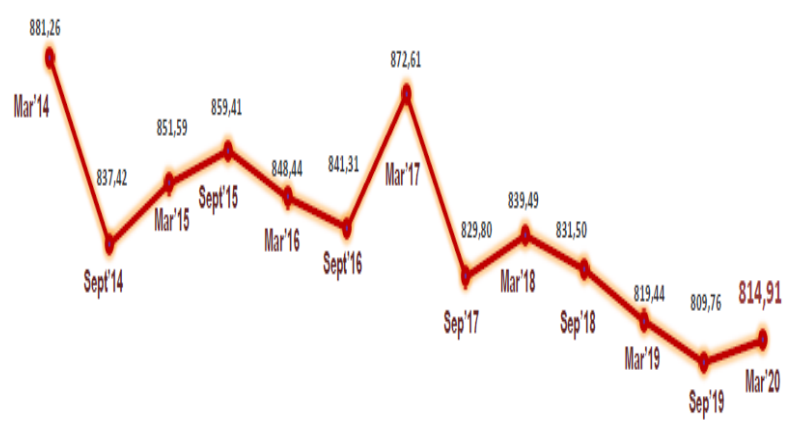

Gambar 1. Jumlah Kemiskinan di Aceh

Faktor yang sering disebut sebagai penyebab kemiskinan dapat terjadi adalah tingkat pendidikan masyarakat yang rendah. Artinya kemiskinan dapat terus berulang dari generasi dan generasi jika tidak segera diputus melalui pemberian pendidikan yang layak untuk seluruh keluarga. Bank Dunia (1990) dalam laporan berjudul Poverty and Human Development mengatakan: The case for human developemnt is not only or even primarily an economic one. Less hunger, fewer child death, and better change of primary education are almost universally accepted as important ends in themselves. Sehingga, ketika ingin melakukan pembangunan manusia yang berdaya saing tidak terbatas pada aspek ekonomi, tapi harus mengutamakan aspek pendidikan untuk kepentingan diri orang miskin guna meningkatkan kehidupan sosial ekonominya (Kamarni 2012; Stamboel 2012).

Pendidikan sangat berpengaruh terhadap pertumbuhan ekonomi karena pendidikan menjadikan setiap orang, termasuk 
orang miskin yang telah mendapatkan akses pendidikan, menjadi pekerja yang berkualitas. Pola yang terbentuk adalah semakin tinggi pendidikan, seseorang maka akan menyediakan tenaga kerja berkualitas yang lebih tinggi, dan tenaga kerja yang berkualitas akan menghasilkan output barang dan jasa dalam jumlah yang lebih banyak dan lebih berkualitas pula yang menuntun mereka mendapatkan keuntungan dan pendapatan yang layak. Stevens Philip (2004) menemukan bahwa peningkatan kualitas tenaga kerja mempunyai hubungan positif dengan pertumbuhan output yang berkontribusi terhadap pertumbuhan ekonomi suatu negara. De Kort (2002) dalam studinya tentang kemiskinan mengatakan jika menguasai teknologi dapat menghasilkan nilai tambah yang mampu mendorong pertumbuhan ekonomi. Dan penguasaan atas teknologi baru dapat tercapai melalui pendidikan.

Berbicara mengenai kemiskinan di Indonesia, maka salah satu kelompok masyarakat yang rentan adalah masyarakat nelayan yang tinggal dan bekerja di sepanjang pesisir pantai Indonesia sebagai nelayan (Utami 2019). Hal yang membuat prihatin adalah kemiskinan tersebut tidak hanya menjerat satu orang dalam satu keluarga, namun seluruh anggota keluarga, termasuk anak-anak nelayan yang seharusnya memiliki masa depan yang cerah. Sebabnya adalah ketika masyarakat tidak mampu mengakses sumber pendapatan yang layak, maka selain kebutuhan primer seperti kebutuhan sandang, pangan, dan papan serta kebutuhan tersier lainnya, kebutuhan atas akses kesehatan dan pendidikan menjadi kebutuhan yang kerap dinomorsekiankan dan tidak menjadi prioritas (Hadar 2004; Huraerah 2013; Jonadi 2002; Stamboel 2012). Padahal seperti dibahas sebelumnya bahwa salah satu cara untuk memutus rantai kemiskinan adalah melalui pendidikan bagi generasi muda seperti anak-anak nelayan.

Penelitian ini bertujuan untuk mengukur apakah kemiskinan berpengaruh terhadap akses pendidikan bagi anak nelayan di Desa Ujung Tanah Kecamatan Samadua Kabupaten Aceh Selatan. Lokasi ini dipilih karena mayoritas masyarakat di desa ini berprofesi sebagai nelayan dan tinggal di kawasan pesisir. Desa Ujung Tanah merupakan salah satu desa yang berada di Kecamatan Samadua Kabupaten Aceh Selatan yang memiliki potensi sumber daya perikanan dan berada di daerah pesisir Barat-Selatan Aceh.

\section{METODE PENELITIAN}

Penelitian ini berbasis pada penelitian kuantitatif eksplanatory karena berusaha menguji hubungan antar-variabel dan menjelaskan hubungan antara keduanya (Ruslan, 2006:15). Variabel X dalam penelitian ini adalah kemiskinan dan variable $\mathrm{Y}$ adalah akses pendidikan. Alasan metode ini digunakan karena melalui metode kuantitatif ini peneliti dapat melakukan generalisasi hasil penelitian melalui pengujian teori yang telah ada pada populasi yang diteliti.

Data penelitian didapatkan melalui kuesioner yang telah dibagikan kepada responden di lokasi penelitian serta didukung dengan wawancara untuk melengkapi data yang telah diperoleeh. Populasi dalam penelitian ini adalah seluruh masyarakat yang tinggal di kawasan pesisir di Desa Ujung Tanah yang bekerja sebagai nelayan yaitu berjumlah 18 orang nelayan. Data yang terkumpul kemudian dianalisis dengan korelasi melalui bantuan software IBM SPSS Statistics versi 20.
Hipotesis adalah jawaban sementara terhadap suatu permasalahan dan merupakan pernyataan paling penting kedudukannya dalam penelitian. Oleh karena itu, hipotesis dalam penelitian ini adalah terdapat pengaruh antara kemiskinan terhadap akses pendidikan anak nelayan, dengan:

1. Ho = Terdapat pengaruh antara kemiskinan terhadap akses pendidikan anak nelayan

2. $\mathrm{Hl}=$ Tidak terdapat pengaruh antara kemiskinan terhadap akses pendidikan anak nelayan

Dengan syarat jika korelasi sama dengan nol (0) berarti mempunyai arti tidak ada hubungan antara dua variabel. Jika korelasi sama dengan satu (+1) maka korelasi artinya kedua variabel mempunyai hubungan linier sempurna (membentuk garis lurus) positif.. Korelasi sempurna seperti ini memiliki arti jika nilai variabel $\mathrm{X}$ naik, maka variabel Y juga naik. Namun, jika korelasi sama dengan minus satu (-1) maka artinya kedua variabel mempunyai hubungan linier sempurna (membentuk garis lurus) negatif. Korelasi sempurna seperti ini mempunyai makna jika nilai $\mathrm{X}$ naik, maka Y turun dan berlaku sebaliknya. Selain itu, analisis melalui pengujian korelasi juga dapat menunjukkan apakah hipotesis diterima atau ditolak dengan menggunakan aturan sebagai berikut: jika nilai signifikasin (Sig. (2-tailed) lebih besar dari 0.05 (p>0.05) maka Ho dapat diterima atau dapat dimaknai jika terdapat pengaruh antara variabel X dan Y. Namun, jika nilai signifikansi p-value lebih kecil yaitu $\mathrm{p}<0.05$ maka tolak hipotesis ditolak dan hipotesis alternative atau $\mathrm{Hl}$ diterima.

\section{HASIL DAN PEMBAHASAN \\ Kemiskinan Pada Masyarakat Nelayan}

Berdasarkan penelitian yang dilakukan terdapat dua variabel yaitu variabel $\mathrm{X}$ adalah kemiskinan dan variable $\mathrm{Y}$ adalah pendidikan anak nelayan. Penelitian dilakukan di rumah-rumah nelayan pada sore hari karena nelayan baru pulang melaut pada sore hari, sedangkan pada pagi hari nelayan pergi melaut untuk mencari ikan. Dalam penelitian ini, daftar pertanyaan diberikan dalam bentuk kuesioner dan didukung dengan wawancara singkat sebagai pelengkap penelitian. Terkait sebaran kemiskinan pada masyarakat nelayan di lokasi penelitian dapat dilihat pada tabel 1 berikut.

Tabel l. Distribusi Tingkat Kemiskinan

\begin{tabular}{ccc}
\hline Kriteria & Frekuensi & Persentasi (\%) \\
\hline Sangat Tinggi & 1 & $5.6 \%$ \\
Sedang & 3 & $2.2 \%$ \\
Rendah & 14 & $72.2 \%$ \\
\hline Jumlah & 18 & $100 \%$ \\
\hline Sumber: Data Penelitian Lapangan (2020)
\end{tabular}

Tabel di atas menunjukkan bahwa dari 18 orang responden yang diteliti telah diperoleh informasi tentang kondisi ekonomi keluarga nelayan yaitu nelayan dengan tingkat pendapatan dengan kriteria sangat tinggi (5.6\%), tingkat pendapatan dengan kriteria sedang (22.2 \%), dan tingkat tingkat pendapatan rendah $(72.2 \%)$. Dengan rincian pendapatan tinggi 1 keluarga, sedang 3 keluarga, dan rendah 14 keluarga. Sehingga totalnya 18 keluarga. Untuk memudahkan pemahaman berikut ditampilkan diagram batang kondisi ekonomi nelayan berdasarkan jumlah keluarga. 


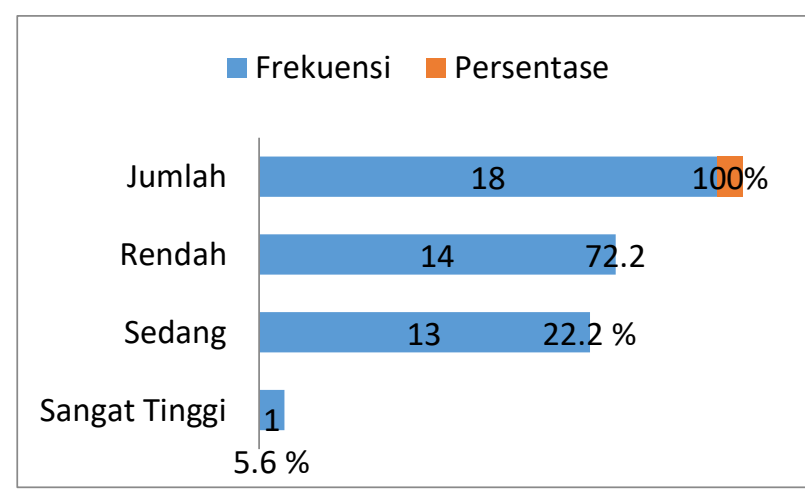

Gambar 2. Kondisi Ekonomi Nelayan

Tingkat kemiskinan pada nelayan dapat diukur dengan menggunakan indikator (1) pendapatan dan (2) kekayaan yang dimiliki oleh nelayan. Indikator pertama, yaitu pendapatan nelayan adalah jumlah penghasilan yang didapatkan nelayan dari hasil mencari ikan dilaut dalam bekerja sebulan penuh (dalam rupiah). Sehingga, berdasarkan jawaban yang diberikan berikut gambaran pendapatan yang diperoleh nelayan.

Tabel 2. Distribusi Pendapatan Nelayan

\begin{tabular}{ccc}
\hline Kriteria (Rp) & Frekuensi & $\begin{array}{c}\text { Persentase } \\
(\%)\end{array}$ \\
\hline $500.000-1.000 .000$ & 14 & $72.2 \%$ \\
$1.000 .000-1.500 .000$ & 3 & $22.2 \%$ \\
$1.500 .000-2.000 .000$ & 1 & $5.6 \%$ \\
\hline Jumlah & 18 & $100 \%$ \\
\hline
\end{tabular}

Sumber: Data Penelitian Lapangan (2020)

Dari tabel di atas dapat dilihat jika berdasarkan 18 nelayan yang menjadi objek penelitian ketika ditanyai terkait jumlah pendapatan, maka jumlah pendapatan nelayan setiap bulannya dapat dibagi dalam beberapa tingkatan berikut: yaitu, terdapat nelayan dengan jumlah pendapatan berkisar antara Rp. 500.000-Rp. 1000.000 (72.2\%) yaitu terdiri atas 14 keluarga nelayan, terdapat nelayan dengan jumlah pendapatan berkisar antara Rp 1.000.000-Rp.1.500.000 (22.2\%) yaitu terdiri atas 3 keluarga nelayan, dan terdapat nelayan dengan jumlah pendapatan berkisar antara Rp.1.500.00-Rp.2000.000 (5.6 \%) yaitu terdiri atas 1 keluarga. Untuk lebih jelasnya, data terkait tingkat pendapatan nelayan tersebut ditampilkan dalam diagram batang di bawah ini.

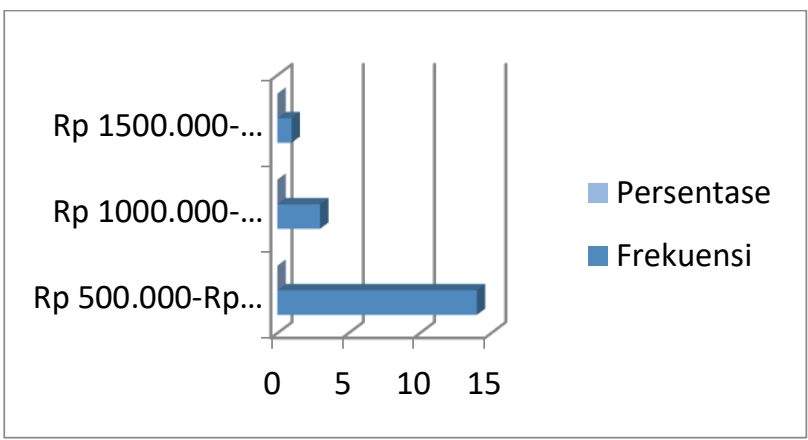

Gambar 3. Pendapatan Nelayan

Indikator kedua, yaitu kekayaan adalah jumlah kekayaan dan aset yang dimiliki oleh nelayan dan dalam penelitian ini diukur dengan tiga hal berikut, yaitu (1) status rumah yang dimiliki, (2) jenis rumah yang ditempati, (3) tipe lantai rumah yang ditinggali. Berdasarkan status kepemilikan rumah, maka nelayan yang telah memiliki rumah sendiri yaitu 13 orang nelayan, rumah sewa 1 orang nelayan, rumah bantuan pemerintah 1 orang nelayan, dan rumah orang tua 3 orang nelayan. Dengan rincian tersebut terlihat bahwa persentase tertinggi adalah rumah atas kepemilikian sendiri $72.2 \%$ dan rumah milik orang tua $16.7 \%$. Sedangkan persentase terendah adalah dengan status rumah sewa 5.6\% dan bantuan rumah dari pemerintah $5.6 \%$.

Berdasarkan tipe rumah yang dimiliki, keluarga nelayan memilki tipe rumah jenis permanen (100\%) karena bagi masyarakat Aceh, termasuk masyarakat nelayan, kepemilikan atas rumah permanen adalah suatu keharusan mengingat tingginya angka kerusakan dan kehilangan rumah akibat kebakaran, gempa, dan tsunami yang kerap terjadi di Aceh. Meskipun demikian, mayoritas rumah-rumah nelayan berlantaikan semen $(61.1 \%)$ dan sisanya berlantaikan keramik $(38.9 \%)$.

Kondisi ekonomi nelayan di Desa Ujung Tanah termasuk ke dalam kriteria rendah (72.2 \%). Hal ini disebabkan karena nelayan di Desa Ujung Tanah kebanyakan berprofesi sebagai nelayan kecil yang bekerja tergantung cuaca dan situasi yang terjadi. Mereka juga tidak memiliki pekerjaan sampingan lainnya yang mampu mendongkrak ekonomi keluarga. Sehingga, ketika cuaca buruk seperti badai, angina kencang, atau pasang air laut terjadi maka masyarakat nelayan ini tidak dapat pergi melaut dan otomatis mereka tidak mempunyai penghasilan namun tetap harus menanggung kebutuhan sel;uruh anggota keluarga. Hal ini yang pada akhirnya menyebabkan ekonomi nelayan rendah, memprihatinkan, dan terus berada dalam kemiskinan. Terutama di lokasi tempat penelitian berlangsung yaitu pada masyarakat nelayan di Desa Ujung Tanah Aceh Selatan.

\section{Tingkat Pendidikan Anak Nelayan}

Tingkat pendidikan pada anak nelayan dapat dilihat melalui jumlah anak nelayan yang telah menempuh jenjang pendidikan tertentu. Berikut tabel untuk memudahkan pemahaman mengenai jumlah anak nelayan yang mengenyam pendidikan.

Tabel 3 Tingkat Pendidikan Anak Nelayan

\begin{tabular}{cccc}
\hline No. & $\begin{array}{c}\text { Tingkat } \\
\text { Pendidikan }\end{array}$ & Jumlah & $\begin{array}{c}\text { Tidak } \\
\text { Bersekolah }\end{array}$ \\
\hline l. & SD & 15 & 3 \\
2. & SMP & 14 & 4 \\
3. & SMA & 12 & 6 \\
4. & S1 & 8 & 10 \\
\hline
\end{tabular}

Sumber: Data Penelitian Lapangan (2020)

Tingkat pendidikan anak nelayan apabila dibagi berdasarkan tingkat/jenjang pendidikan maka dapat dibagi dalam beberapa jenjang, yaitu pendidikan dasar yaitu persentase terendah berada pada satu keluarga nelayan (5.6\%) yaitu terdapat sekitar 4-6 orang anak yang sekolah, tiga keluarga nelayan (16.7\%) tidak ada anak yang bersekolah, empat keluarga nelayan (22.2\%) sekitar 2-4 orang anak yang sekolah. Dan persentase tertinggi berada pada 10 keluarga nelayan (55.6\%) sekitar 1-2 orang anak nelayan. Pada jenjang pendidikan SMP, persentase terendah berada pada satu keluarga nelayan (5.6\%) yaitu sekitar 4-6 orang anak yang sekolah, dua keluarga nelayan (11.1\%) sekitar 2- 4 orang anak yang sekolah, 4 keluarga nelayan (22.2\%) tidak ada anak yang 
bersekolah dan persentase tertinggi berada pada 11 keluarga nelayan $(61.1 \%$ ) yaitu sekitar $1-2$ orang anak yang sekolah.

Tingkat pendidikan SMA yang persentase terendah berada pada tiga keluarga nelayan (16.7\%) sekitar 2-4 orang anak yang sekolah, enam keluarga nelayan (33.3\%) tidak ada anak yang sekolah. Dan persentase tertinggi berada pada Sembilan keluarga nelayan (50\%) sekitar 1-2 orang anak yang bersekolah. Pada tingkat perguruan tinggi, persentase terendah berada pada delapan keluarga nelayan (44.4\%) sekitar 1-2 orang anak yang kuliah dan persentase tertinggi berada pada 10 keluarga nelayan (55.6 \%) yang tidak kuliah. Dari tingkatan pendidikan anak nelayan dapat kita lihat persentase yang terendah berada pada tingkat perguruan tinggi.

Hal tersebut dapat terjadi disebabkan oleh faktor eksternal anak nelayan yaitu tuntutan kebutuhan ekonomi yang tinggi. Nelayan memiliki kewajiban untuk memenuhi kebutuhan sehari-hari dan juga memberikan akses pendidikan kepada semua anak-anaknya. Biasanya, pendidikan di jenjang $\mathrm{Sl}$ adalah jenjang pendidikan yang tidak mampu diberikan oleh nelayan kepada anak-anaknya sehingga anak nelayan tidak mampu melanjutkan pendidikan Sl. Namun, selain itu, terdapat faktor internal, yaitu factor dalam diri anak nelayan yang menyebabkan mereka tidak termotivasi untuk melanjutkan pendidikan ke jenjang yang lebih tinggi. Faktor internal tersebut adalah tidak adanya kemauan dari dalam diri anak nelayan untuk melanjutkan ke tingkat pendidikan yang lebih tinggi. Biasanya hal ini di dorong oleh pengaruh lingkungan yang mempengaruhi pola pikir anak nelayan untuk tidak melanjutkan pendidikan dan lebih memilih mengikuti jejak orang tuanya untuk bekerja sebagai nelayan.

Selain itu, perhatian orangtua yang kurang terhadap pendidikan anak nelayan juga menjadi penyebab mereka merasa tidak mendapat dukungan dan putus asa terhadap masa depan pendidikan yang seharusnya mereka dapatkan. Padahal, ketidakpedulian orang tua mereka yang nelayan juga didasari oleh hal yang sama yaitu rendahnya pendidikan yang menyebabkan rendahnya kesadaran tentang pentingnya pendidikan. Dengan beberapa alasan tersebut maka mayoritas anak nelayan yang seharusnya mendapatkan akses pendidikan hingga jenjang tertinggi memilih tidak melanjutkan pendidikan karena status ekonomi yang kurang ataupun karena keinginan untuk bekerja, ataupun keinginan dari dirinya sendiri untuk membantu orang tua dalam memenuhi kebutuhan hidup atau diperintah orangtua, sehingga hanya sebagaian kecil dari anak nelayan yang melanjutkan pendidikan sampai perguruan tinggi.

Berdasarkan penelitian yang telah dilakukan tentang pengaruh kemiskinan terhadap akses pendidikan anak nelayan di Desa Ujung Tanah Kecamatan Samadua Kabupaten Aceh Selatan, maka dapat dilihat jika kemiskinan sangat berpengaruh terhadap kemampuan ekonomi keluarga, termasuk di dalamnya akses pendidikan untuk anak nelayan. Alasannya adalah, seorang kepala keluarga yang berprofesi sebagai nelayan perlu mengeluarkan biaya ekstra untuk pendidikan anak-anaknya, sedangkan di saat yang sama tetap harus memenuhi kebutuhan p;okok setiap anggota keluarga seperti sandang, pangan, dan papan. Besaran biaya pendidikan yang harus disiapkan dan dibayarkan oleh nelayan semakin besar seiring jenjang pendidikan yang semakin tinggi. Oleh sebab itu, kemiskinan berpengaruh terhadap pendidikan anak terutama pendidikan anak di tingkat lanjut seperti jenjang strata satu (S1).
Berbicara mengenai tanggungan dalam setiap keluarga nelayan, maka pendapatan nelayan yang berada pada kisaran Rp.500.000-Rp.1000.000 per bulan, rata-rata memiliki tiga atau empat orang anak. Hal ini menyebabkan kepala keluarga yang berprofesi sebagai nelayan kesulitan untuk mengakses pendidikan yang lebih tinggi untuk anak-anaknya dan memprioritaskan pendapatan yang dimiliki untuk memenuhi kebutuhan primer seperti sandang (pakaian), makanan yang dapat dikonsumsi seluruh anggota keluarga (pangan), dan rumah yang layak huni dan permanen (papan) untuk ditempati seluruh anggota keluarga. Sedangkan, mereka tidak terbiasa dan tidak bisa menabung karena tingginya kebutuhan keluarga yang harus dipenuhi setiap harinya. Oleh karena itu, motivasi untuk keluar dari siklus kemiskinan melalui pendidikan anak belum menjadi prioritas bagi nelayan.

\section{Pengaruh Kemiskinan Terhadap Pendidikan Anak Nelayan}

Untuk mengetahui apakah terdapat pengaruh kemiskinan terhadap akses pendidikan yang didapatkan anak nelayan maka perlu untuk dilakukan pengujian korelasi seperti ditampilkan dalam data berikut.

Tabel. 4 Uji Kolerasi Jumlah Anak yang Tamat SD dan Penghasilan Nelayan Per Bulan

\begin{tabular}{ccc}
\hline & & $\begin{array}{c}\text { Penghasilan } \\
\text { Per Bulan }\end{array}$ \\
\hline $\begin{array}{c}\text { Jumlah anak yang } \\
\text { tamat SD }\end{array}$ & Pearson & -.252 \\
& Correlation & .313 \\
& Sig. (2-tailed) & $\mathrm{N}$
\end{tabular}

\section{Sumber: SPSS Statistics versi 20.}

Berdasarkan nilai signifikasi Sig. (2-tailed) N: 18 dari tabel di atas maka dapat diketahui jika nilai Sig. (2-tailed) antara jumlah anak yang tamat SD dan penghasilan responden adalah $0.313<0.05$ dengan korelasi pearson adalah -0.252, maka korelasi antara kedua variabel bernilai negatif. Korelasi negatif artinya kedua variabel mengalami perubahan kearah yang berlawanan. Semakin tinggi variabel $\mathrm{X}$ maka semakin rendah variabel Y begitu pula sebaliknya semakin rendah variabel X maka semakin tinggi variabel $Y$. Maka jumlah anak yang tamat SD memiliki kolerasi terhadap penghasilan responden (nelayan) per bulan. Selain itu, berdasarkan aturan, jika nilai Sig. (2-tailed) lebih besar dari 0.05 di mana dalam penelitian ini adalah 0.313 atau nilai signifikansi $\mathrm{p}$-value sebesar $0.313>0.05$ maka hipotesis diterima atau terdapat pengaruh antara pendapatan terhadap akses pendidikan pada anak nelayan yang mengenyam pendidikan Sekolah Dasar (SD).

Tabel. 5 Uji Kolerasi Jumlah Anak yang Tamat SMP dan Penghasilan Nelayan Per Bulan

\begin{tabular}{ccc}
\hline & & $\begin{array}{c}\text { Penghasilan } \\
\text { Per Bulan }\end{array}$ \\
\hline $\begin{array}{c}\text { Jumlah anak yang } \\
\text { tamat SMP }\end{array}$ & Pearson & -.258 \\
& Correlation & .301 \\
& Sig. (2-tailed) & 18 \\
\hline
\end{tabular}

Sumber: SPSS Statistics versi 20.

Berdasarkan nilai signifikasi Sig. (2-tailed) N: 18 dari tabel di atas maka dapat diketahui jika nilai Sig. (2-tailed) antara jumlah anak yang tamat SMP dan penghasilan responden adalah 0.301>0.05 dengan korelasi pearson adalah -0.258 
Korelasi antara kedua variabel menunjukkan bernilai negatif yaitu -0.143. jumlah anak SMP dan umur responden adalah 0.301> 0.05 dengan pearson correlation -0.258. Maka jumlah anak yang tamat SMP memiliki korelasi terhadap penghasilan responden (nelayan) per bulan. Bentuk dari kedua variabel ini negatif, artinya semakin tinggi variabel $\mathrm{X}$ maka semakin rendah variabel $\mathrm{Y}$ begitu pula sebaliknya semakin rendah variable $\mathrm{X}$ maka semakin tinggi variabel Y. Selain itu, berdasarkan aturan, jika nilai Sig. (2-tailed) lebih besar dari 0.05 di mana dalam penelitian ini adalah 0.301 atau nilai signifikansi p-value sebesar $0.301<0.05$ maka hipotesis diterima atau terdapat pengaruh antara pendapatan nelayan terhadap akses pendidikan pada anak nelayan.

Tabel. 6 Uji Colerasi Jumlah Anak yang Tamat SMA dan Penghasilan Nelayan Per Bulan

\begin{tabular}{ccc}
\hline & & $\begin{array}{c}\text { Penghasilan } \\
\text { Per Bulan }\end{array}$ \\
\hline $\begin{array}{c}\text { Jumlah anak yang } \\
\text { tamat SMA }\end{array}$ & Pearson & -140 \\
& Correlation & .579 \\
& Sig. (2-tailed) & 18 \\
\hline
\end{tabular}

Sumber: SPSS Statistics versi 20.

Berdasarkan nilai signifikasi Sig. (2-tailed) N: 18 dari tabel di atas maka dapat diketahui jika nilai Sig. (2-tailed) antara jumlah anak yang tamat SMA dan penghasilan responden adalah $0.579>0.05$ dengan korelasi pearson adalah -0.140 maka korelasi antara kedua variabel bernilai negatif. Korelasi negatif artinya kedua variabel mengalami perubahan kearah yang berlawanan, yakni semakin tinggi variabelX maka semakin tinggi variabel $\mathrm{Y}$ begitu pula sebaliknya semakin rendah variabel X maka semakin rendah variabel Y. Maka jumlah anak yang tamat SMA memiliki kolerasi terhadap penghasilan responden (nelayan) per bulan. Selain itu, berdasarkan aturan, jika nilai Sig. (2-tailed) lebih besar dari 0.05 di mana dalam penelitian ini adalah 0.579 atau nilai signifikansi $p$-value sebesar $0.579>0.05$ maka hipotesis diterima atau ada pengaruh antara pendapatan nelayan terhadap akses pendidikan anak nelayan

Tabel. 7 Uji Colerasi Jumlah Anak yang Tamat Perguruan Tinggi (S1) dan Penghasilan Nelayan Per Bulan

\begin{tabular}{ccc}
\hline & & $\begin{array}{c}\text { Penghasilan } \\
\text { Per Bulan }\end{array}$ \\
\hline $\begin{array}{c}\text { Jumlah anak yang } \\
\text { tamat SMA }\end{array}$ & Pearson & -.129 \\
& Correlation & .610 \\
& Sig. (2-tailed) & 18 \\
\hline
\end{tabular}

Sumber: SPSS Statistics versi 20.

Berdasarkan nilai signifikasi Sig. (2-tailed) N: 18 dari tabel di atas maka dapat diketahui jika nilai Sig. (2-tailed) antara jumlah anak yang tamat Perguruan Tinggi (Sl) dan penghasilan responden (nelayan) adalah $0.610>0.05$ dengan korelasi pearson adalah -0.129 maka korelasi antara kedua variabel bernilai negatif. Korelasi negatif artinya kedua variabel mengalami perubahan kearah yang berlawanan, yakni semakin tinggi variabel $X$ maka semakin rendah variabel $Y$ begitu pula sebaliknya semakin rendah variable $X$ maka semakin tinggi variabel Y. Maka jumlah anak yang tamat SMA memiliki kolerasi terhadap penghasilan responden (nelayan) per bulan. Selain itu, berdasarkan aturan, jika nilai Sig. (2-tailed) lebih besar dari 0.05 di mana dalam penelitian ini adalah 0.610 atau nilai signifikansi $\mathrm{p}$-value sebesar $0.610>0.05$ maka hipotesis diterima atau ada pengaruh antara pendapatan nelayan terhadap akses pendidikan anak nelayan.

\section{KESIMPULAN}

Dari hasil penelitian tentang pengaruh antara kemiskinan nelayan (X) yang diukur dengan pendapatan nelayan setiap bulannya terhadap akses pendidikan anak nelayan (Y) maka dapat disimpulkan sebagai berikut:

1. Berdasarkan perhitungan korelasi sprearman yang telah dilakukan, maka dapat dilihat jika pada jenjang SD angka signifikansi $0.313<0.05$, SMP angka signifikansi 0.301 > 0.05, angka signifikansi SMA $0.579>0.05$, angka signifikansi S1 $0.610>0.05$. Dengan syarat, jika angka signifikansi atau p>0.05 artinya hipotesis diterima dan p $<0.05$ hipotesis ditolak. Sehingga kesimpulannya adalah terdapat pengaruh antara kemiskinan dan akses pendidikan anak nelayan di jenjang pendidikan SD, SMP, SMA, dan Perguruan Tinggi.

2. Pengujian korelasi antara kemiskinan dan akses pendidikan pada anak nelayan menunjukkan arah yang negatif di setiap jenjang pendidikan. Arah negatif artinya kedua variabel menunjukkan arah yang berlawanan yaitu semakin tinggi variabel $\mathrm{X}$ maka semakin rendah variabel $\mathrm{Y}$ begitu pula sebaliknya semakin rendah variabel $X$ maka semakin tinggi variabel Y. Maka pada jenjang SD, SMP, SMA, dan Sl korelasi menunjukkan semakin tinggi kemiskinan maka semakin rendah pendidikan. Maka hipotesis diterima yaitu terdapat korelasi antara kemiskinan dengan akses pendidikan.

3. Sehingga, kesimpulan dari penelitian ini adalah hipotesis (Ho) diterima yaitu terdapat pengaruh antara kemiskinan (X) dengan pendidikan (Y) pada anak nelayan. Dan arah korelasinya bersifat negatif atau berlawanan arah yaitu ketika kemiskinan (yang ditunjukkan dengan rendahnya pendapatan per/bulan) tinggi maka pendidikan pada anak nelayan rendah. Begitu pula sebaliknya, apabila angka kemiskinan rendah pada nelayan maka akses pendidikan pada anak nelayan semakin tinggi (terbuka) yaitu anak nelayan dapat mengakses pendidikan hingga jenjang pendidikan SD, SMP, SMA, dan Perguruan Tinggi (S1) dengan baik.

\section{REFERENSI}

Agusta, Ivanovich. 2014. Diskursus, Kekuasaan, Dan Praktik Kemiskinan. Jakarta: Yayasan Pustaka Obor Indonesia.

Alfian. 1980. Kemiskinan Struktural. Jakarta: YIIS.

Hadar, Ivan A. 2004. Utang, Kemiskinan Dan Globalisasi : Pencarian Solusi Alternatif. Yogyakarta: Lapera Pustaka Utama.

Huraerah, A. 2013. "Strategi Kebijakan Penanggulangan Kemiskinan Di Indonesia." Jurnal Ilmu Kesejahteraan Sosial 12(1): 3-13.

Ikhsan, Ikhsan. 2015. "Relasi Otonomi Khusus Dan Pengurangan Kemiskinan Di Provinsi Aceh." Jurnal Public Policy 1(1): 1-13. http://jurnal.utu.ac.id/jppolicy/article/view/698.

Jonadi, A. 2002. "Analisis Pertumbuhan Ekonomi Dan Kemiskinan Di Indonesia.” Jurnal Kajian Ekonomi 1(1): 14064.

Kamarni, N. 2012. "Analisis Modal Sosial Sebagai Salah Satu Upaya Dalam Pengentasan Kemiskinan (Studi Kasus: Rumah TanggaMiskin Di Kecamatan Koto Tangah Kota 
Padang." Jurnal Manajemen dan kewirusahaan 3(3): 36-52.

De Kort, Joop. 2002. How Rights Are Economic and Social Rights? The Interaction Between Law and Economics in Human Rights. ed. Ferdinand Feldbrugge and William Simons. Kluwer: Human Rights in Russia and Eastern Europe.

Kuncoro. 2002. Dasar-Dasar Analisis Kemiskinan. Jakarta: Grapindo Persada.

Okezone. 2018. "Dana Otsus Rp56 Triliun Lebih, Kemiskinan Di Aceh Justru Meningkat." https://news.okezone.com/read/2018/07/17/340/1923627/da na-otsus-rp56-triliun-lebih-kemiskinan-di-aceh-justrumeningkat (March 10, 2020).

Seran, Sirilius. 2017. "Hubungan Antara Pendidikan, Pengangguran, Dan Pertumbuhan Ekonomi Dengan Kemiskinan." Jurnal Ekonomi KuantitatifTerapan 10(1): 59-71.

Stamboel, Kemal Azis. 2012. Panggilan Keberpihakan: Strategi Mengakhiri Kemiskinan Di Indonesia. Jakarta: Gramedia Pustaka Utama.

Stevens, Philip Andrew. 2004. "Academic Salaries in the UK and US." National Institute Economic Review 190(1): 104-13.

Utami, Nindi Putri dkk. 2019. "Peran Panglima Laot Dalam Mengatasi Hasil Tangkapan Ikan Yang Melimpah Studi Kasus: Gampong Panggong Aceh Barat.” Public Policy 5(1): 1-12. 